\author{
Saeid Shiukhy Soqanloo* \\ Faculty member instructor of Agrometeorology, Department \\ of water engineering, Sari Agricultural sciences and Natural \\ Resources University, Mazandran, Iran \\ Dates: Received: 04 August, 2015; Accepted: 02 \\ September, 2015; Published: 02 September, 2015 \\ *Corresponding author: Saeid Shiukhy Soqanloo, \\ Department of water engineering, Sari Agricultural \\ sciences and Natural Resources University, \\ Mazandran, Iran, Tel : 0981133687560; E-mail: \\ saeid.shiukhy@gmail.com \\ www.peertechz.com \\ ISSN: 2455-488X \\ Keywords: Fruit quality; Vitamin C; Arid and semi- \\ arid climates
}

\section{Research Article \\ Effect of Different Regional Climates on Persimmon Quality}

\section{Introduction}

Persimmon (Diospyros kaki) belongs to the family Ebenaceae is widely grown in the climatic zones range in the world. This species is native to Japan and has wide leaves and delicious fruit. Planting this tree, because its fruits, first developed in Western countries and in the first decade of the $19^{\text {th }}$ century was introduced to California and Southern Europe [1], and later entered Iran. And has also in many parts of the country expanded. In color, the ripe fruit of the cultivated strains range from light yellow-orange to dark red-orange depending on the species and variety. The fruit has a high tannin content which makes the immature fruit astringent and bitter. It is edible in its crisp firm state, but has its best flavor when allowed to rest and soften slightly after harvest [2].

Fruit harvested at different times have a significant impact on fruit quality characteristics [3-5]. Harvest index, based on experience and ecological conditions of climate zones evaluated at the end of December is completed. Harvest index, based on experience and ecological conditions of climate zones is complete at the end of December. Fruit picked before ripening to increase during storage and maintaining quality characteristics it is very important. Fruits that are harvested too early, smaller and color, aroma and taste them down $[6,7]$.

The plant growth is influenced by genetic and environmental characteristics, so it could be more due to the differences in a variety of environmental factors to genetic changes. Thus, the lack of environmental factors, plant growth will be disorder and will stop [8]. Temperature is one of the factors affecting photosynthesis and plant metabolism at the cellular level. Seasonal and diurnal temperature changes has a significant effect on plant growth [9].

The difference in the temperature range can be attributed to variations in latitude, topography, proximity to large bodies of water represented. This constructive climate, due to the high heat capacity of water, this constructive climate, due to the high heat capacity of water, as evident in annual and the diurnal temperature range (DTR). Generally, higher temperatures lead to an increase in the rates of sugar accumulation in the fruit ripening and organic acids degardation, while low temperatures can lead to a reduction in the organic acids degradation and rates of sugar accumulation [10]. According to the daily temperature range, grape quality varies during the ripening period, because this parameter affects the sugar, anthocyanin compounds and as well as the aroma. During the day, photosynthesis occurs and at night photosynthesis product move from the source leaves to the fruit. Cool night temperature in during grape ripening favor the sugar accumulation and restrict the vegetative growth [11], Mori et al. [12], reported that at higher temperatures from $10^{\circ} \mathrm{C}$ respiratory activity increases exponentially.

Persimmon fruit is rich in the carbohydrates, organic acids, vitamins (especially $\mathrm{A}$ and $\mathrm{C}$ ), minerals, phenolic compounds and carotenoids $[13,14]$. Phenolic compounds with ascorbic acid protects the body against oxidative stress $[15,16]$. The amount of ascorbic acid (vitamin C) is a basic indicator to define the marketability of fruit and vegetables [17]. It is believed that vitamin $\mathrm{C}$ acts as an intermediate in the biosynthesis and metabolism of substances that are involved in the immune system [18]. Ebrahimzadeh et al. [19], reported a significant difference among citrus species for vitamin $\mathrm{C}$ contents. Therefore, the aim of this study was to investigate the effects of different climate zones, as a manifestation of changes in temperature and humidity, is the persimmon fruit quality.

\section{Material and Methods \\ Climate regions features}

In order to evaluate the effect of different climatic conditions on biochemical properties of persimmon fruit, from five areas (cities) with different climatic conditions, including: Sari $\left(36.56^{\circ} \mathrm{N}, 53.06^{\circ}\right.$ E), Yazd $\left(31.89^{\circ} \mathrm{N}, 54.36^{\circ} \mathrm{E}\right)$, Kiasar $\left(36.23^{\circ} \mathrm{N}, 53.54^{\circ} \mathrm{E}\right)$, Kashan $\left(33.98^{\circ} \mathrm{N}, 51.47^{\circ} \mathrm{E}\right)$ and Shahrud $\left(36.41^{\circ} \mathrm{N}, 54.97^{\circ} \mathrm{E}\right)$ were sampled. Characteristics and geographical areas listed in Table 1. 


\section{Meteorological data}

Daily data of maximum temperature, minimum temperature, average temperature and average relative humidity (During the growing season in 2014) of Iran Meteorological Organization (IMO) were received. Annual average calculated in Table 2 were reported. The difference between the dailymaximum and minimum temperature, the diurnal temperature range (DTR) was calculated.

$$
\mathrm{DTR}_{\left({ }^{\circ} \mathrm{C}\right)}=T_{\text {max }}-T_{\text {min }}
$$

\section{Fruits}

In this study, based on a randomized complete block design with three replications, from trees that have the same morphological characteristics, such as height, age and canopy, were sampled. To harvest fruit, the color index similar to citrus fruit (orange lightorange) was used.

\section{Measuring of biochemical characteristics of fruit}

To measure vitamin C from 2,6-Dichloroindophenoltitration method was used and the amount of vitamin $\mathrm{C}$ was calculated from the following equation [20].

$$
\operatorname{Vit}_{(\mathrm{c})}\left(\frac{\mathrm{mg}}{100}\right)=\frac{\mathrm{e}^{*} \mathrm{~d} * \mathrm{~b}}{\mathrm{c} * \mathrm{a}} \times 100
$$

Total soluble solid (TSS) in the juice was determined with a hand- refract meter (PR-32 palette, Atago Co., Japan) at room temperature and expressed as a Percentage [21]. Titratable acidity (TA) was determined in the presence of phenolphthalein $(\mathrm{pH}=8.2)$ and expressed as citric acid percent (Rabiei, 2006). $\mathrm{pH}$ of the juice was measured using a pH meter (Jenway,3020).To determine the amount of chlorophyll and carotenoid, first $0.5 \mathrm{~g}$ of sample was pulverized in the presence of $10 \mathrm{ml}$ acetone $80 \%$. The solution was centrifuged for $5 \mathrm{~min}$ at 5000rpm. Using a spectrophotometer (UV-1800 PC), the absorption rate in wavelength of 480, 510, 645 and $663 \mathrm{~nm}$ was recorded. Acetone $80 \%$ was used as a blank spectrophotometry [22]. The following formula for the amount of chlorophyll $a, b, a * b$ and carotenoid were calculated:

Fruit biochemical data were analyzed using ANOVA of SAS software (SAS 9.1), and the SNK post hoc test was employed to compare treatment means.

$$
\begin{aligned}
& \operatorname{Chloa}(m g / g . f . w)=12.7(A 663)-2.69(\mathrm{~A} 645) * \frac{V}{1000} * W \\
& \operatorname{Chlob}(m g / g . f . w)=12.9(A 645)-2.69(\mathrm{~A} 663) * \frac{V}{1000} * W \\
& \text { Chloa } \times b(m g / g . f . w)=20.2(A 645)-8.02(\text { A6663 }) * \frac{V}{1000} * W \\
& \text { Car }(m g / g . f . w)=7.6(A 480)-1.49(\text { A } 510) * \frac{V}{1000} * W
\end{aligned}
$$

\section{Result and Discussion}

\section{Vitamin C (ascorbic acid) content}

Different climatic conditions in the regions studied, very

\begin{tabular}{|c|c|c|c|c|c|c|}
\hline Regional climate & Longitude ( $\left.{ }^{\circ} \mathrm{E}\right)$ & Latitude $\left({ }^{\circ} \mathrm{N}\right)$ & ${ }^{*} \mathrm{AMSL}(\mathrm{m})$ & ${ }^{* \star}$ temperature $\left({ }^{\circ} \mathrm{C}\right)$ & ${ }^{* *}$ precipitation $(\mathrm{mm})$ & The number of frost day \\
\hline Sari & $53.06^{\circ}$ & $36.56^{\circ}$ & 132 & 15 & 789.2 & 11 \\
\hline Shahrud & $54.97^{\circ}$ & $36.41^{\circ}$ & 1130 & 12 & 375 & 98 \\
\hline Kashan & $51.47^{\circ}$ & $33.98^{\circ}$ & 1570 & 18 & 116 & 65 \\
\hline Kiasar & $53.54^{\circ}$ & $36.23^{\circ}$ & 1378 & 13 & 656 & 51 \\
\hline Yazd & $54.36^{\circ}$ & $31.89^{\circ}$ & 1230 & 20.2 & 62 & 55 \\
\hline
\end{tabular}
significant effect on the amount of ascorbic acid $(\mathrm{P} \leq 0.01)$. Based on research findings, fruits that were harvested from the areas of climate

\begin{tabular}{|c|c|c|c|c|c|}
\hline Regional climate & Vitamin $* *(m g / 100 \mathrm{ml})$ & $\begin{array}{l}\text { Chlorophyll a } \\
* * *(m g / g . f . w)\end{array}$ & $\begin{array}{l}\text { Chlorophyll b } \\
\text { (mg/g.f.w) }\end{array}$ & $\begin{array}{l}\text { Chlorophyll ab } \\
\text { (mg/g.f.w) }\end{array}$ & Carotenoid (mg/g.f.w) \\
\hline Sari & $0.75 c^{*}$ & $0.05 a$ & $0.03 a$ & $0.04 a$ & $0.22 b$ \\
\hline Shahrud & $1.43 b$ & $0.01 b$ & $0.02 a$ & $0.03 a$ & $0.19 b$ \\
\hline Kashan & $1.63 a$ & $0.01 b$ & $0.02 \mathrm{a}$ & $0.03 a$ & $0.24 b$ \\
\hline Kiasar & $1.40 \mathrm{~b}$ & $0.01 b$ & $0.02 a$ & $0.03 a$ & $0.19 b$ \\
\hline Yazd & $1.74 \mathrm{a}$ & $0.06 a$ & $0.03 a$ & $0.04 a$ & $0.42 a$ \\
\hline \multicolumn{6}{|c|}{$\begin{array}{l}\text { ** Mg of fruit weight per the } 100 \mathrm{ml} \text { fruit juice. } \\
\star \star \star \\
\text { * } \mathrm{Mg} \text { of fruit weight per the gram fruit fresh weight. } \\
{ }^{*} \text { means along different treatment on last column that carry the same letter have no significance difference }(5 \%) \text {. }\end{array}$} \\
\hline
\end{tabular}
Yazd and Kashan, total vitamin C contentmore than the fruits that were harvested from other parts of the climate (Table 2).

According to Table 2, the highest vitamin $\mathrm{C}$ content of the fruit

Table 2: Vitamin C, chlorophyll a, b and ab activity and carotenoid content of fruit harvested in different regional climate, during growth of persimmon fruit in 2012. 
harvested from Yazd and Kashan climate regions, respectively, with values of 74.1 and $63.1(\mathrm{mg} / 100 \mathrm{ml}$ of fruit juice) and the lowest level was in sari climate region $(76.0 \mathrm{mg} / 100 \mathrm{ml}$ of fruit juice). Many actions and reactions that occur in plants, each to be affected by temperature fall. The role of temperature on photosynthesis and respiration reactions can be noted among. The net value of the daily work of photosynthesis by plants and accumulated difference between the amount of carbohydrate that is made during the day and the amount of carbohydrate per day ( 24 hours) consumed by respiration. Plant for biological activity and construction, only products that is added daily during the photosynthesis process, it can consume or store it in an organ or other plant organs accumulated. However, it was found that when the total daily respiration is more than the daily photosynthesis, the plant products that already had accumulated storage consumes, if the trend continues, with a lack of food plants will be lost. With increasing temperature, respiratory rate becomes faster than the rate of photosynthesis, and the pure substance that is made daily by the plant reduced. The process of photosynthesis is limited to circumstances where there is enough light during the day, while the respiration process continues over a day (every hour of the day) the night temperature?? Has an important influence IIe on the pure substance that is made daily as a result of photosynthesis in plants. By breathing at $25^{\circ} \mathrm{C}$, more food is consumed than $15^{\circ} \mathrm{C}$ [23].

Thus, areas with relatively cool nights and warm days are the pure substance stored in the plant and the yield will increase. On the contrary, in areas that are relatively warm nights of the pure substance stored and the yield is generally low. Based on the findings of the report could be said that in areas where the temperature difference between day and night was higher than other regions, have increased the amount of material stored and also had a higher qualitative characteristics. Therefore, it is believed that the reason for the higher rate of vitamin C fruits harvested from climatic regions of Kashan, Yazd, and shahrud than the Kiasar and Sari climate is the temperature Hamedani et al. [24]. Temperature difference between day and night for them. Hamedani et al. [24], Showed that the amount of vitamin
C content in the orange fruit is affected by the temperature and the amount varied at different temperatures.

\section{Chlorophyll and carotenoid contents of fruit}

Determining the chlorophyll $\mathrm{a}$ and $\mathrm{b}$ and $\mathrm{ab}$ activity fruits harvested from different climatic regions showed that the climatic conditions of the region had a significant effect on the chlorophyll a activity $(\mathrm{P} \leq 0.01)$. While climatic conditions of the regions studied the activity of chlorophyll $b$ and $a b$ fruit had no significant effect (Figure 1). Results showed that the chlorophyll a activity affected by regional climate. As fruits that were harvested from the region of Yazd, highest of the chlorophyll a activity, compared with other parts of the climate. While, the amount of activity chlorophylls $\mathrm{b}$ and $\mathrm{ab}$ in different climatic conditions studied did not change. Also, different climatic conditions have a significant effect on fruit carotenoids content $(P \leq 0.01)$. Based on the results, the carotenoid content of fruits that harvested from the region of Yazd, a higher rate than other parts of the climate (Figure 1).

In the early season vegetative growth to reproductive parts (fruits) more. Therefore, many materials are synthesized by the leaves of the vegetative organs stores; but with the growth of fruit photosynthetic products in the fruit stored [25]. Therefore, the amount of chlorophyll in fruit during ripening is reduced (Fattahi moghaddam 2010). As the fruits exposed to higher and lower temperatures than optimal, the fruit quality decreases. Perveen et al. [26], showed at temperatures close to zero and less than zero, the amount of chlorophyll a, b and carotenoid content in wheat was zero temperature. Sharma et al. [27], reported that, at a temperature close to $30^{\circ} \mathrm{C}$, chlorophyll and carotenoid content is highest than $45^{\circ} \mathrm{C}$.

\section{Acidity (pH), Titratable Acidity (TA) and Total Soluble Solid (TSS)}

The results showed that the different climatic conditions had a significant effect on $\mathrm{pH}, \mathrm{TA}$ and TSS of fruit $(\mathrm{P} \leq 0.01)$. Thus, the fruits harvested in the Kashan region with value 6.6 had the highest

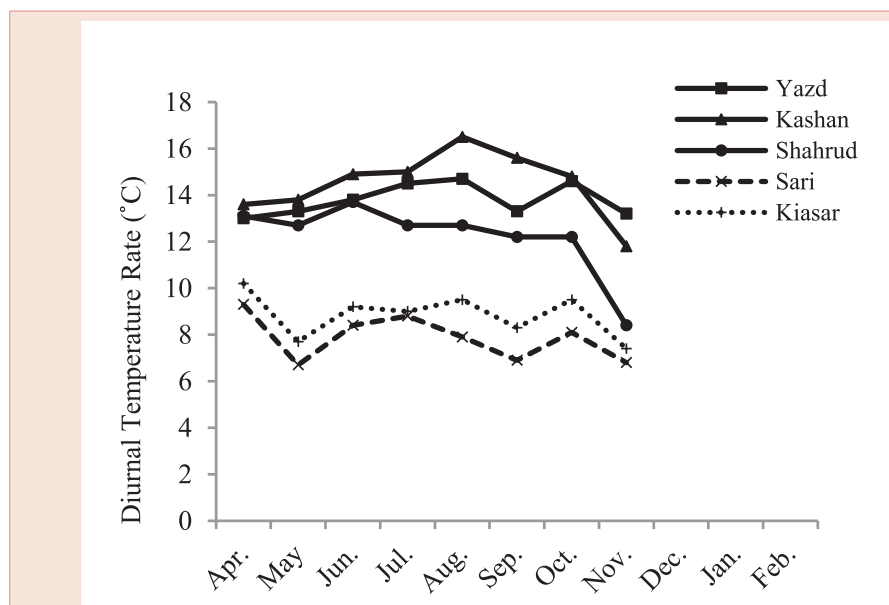

Time (month)

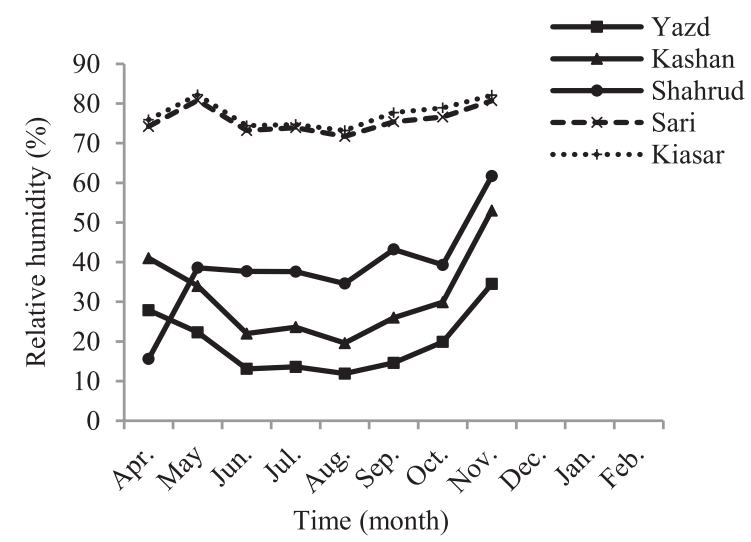

Figure 1: Diurnal Temperature Rate (DTR) (a) and Relative Humidity (b) changes, during growth of persimmon fruit in 2014. 
Table 3: Acidity (pH), Titrable Acidity (TA) and Total Soluble Solid (TSS) of fruit harvested in different regional climate, during growth of persimmon fruit in 1392.

\begin{tabular}{|c|c|c|c|}
\hline $\begin{array}{c}\text { Regional } \\
\text { climate }\end{array}$ & $\begin{array}{c}\text { Acidity } \\
(\mathbf{p H})\end{array}$ & $\begin{array}{c}\text { Titratable acidity } \\
\text { (TA\%) }\end{array}$ & $\begin{array}{c}\text { Total soluble solidity } \\
\text { (TSS) }\end{array}$ \\
\hline Sari & $6.3 \mathrm{~b}$ & $0.01 \mathrm{~d}$ \\
\hline Shahrud & $6.3 \mathrm{~b}$ & $0.04 \mathrm{a}$ \\
\hline Kashan & $6.6 \mathrm{a}$ & $0.02 \mathrm{c}$ \\
\hline Kiasar & $6.4 \mathrm{~b}$ & $0.02 \mathrm{c}$ & $20.1 \mathrm{~b}$ \\
\hline Yazd & $6.3 \mathrm{~b}$ & $0.03 \mathrm{~b}$ & $17.1 \mathrm{c}$ \\
\hline Means along different treatment on last column that carry the same letter have no significance difference $(5 \%)$.
\end{tabular}

Means along different treatment on last column that carry the same letter have no significance difference (5\%).

$\mathrm{pH}$ while the highest TA and TSS $(0.04$ and $22.13 \mathrm{mg} / 100 \mathrm{ml})$ was for the shahrud area, (Table 3). The physiological activity of fruit in many species with exposure to high and low temperatures reduced [28]. Fruit soluble solids content more dependent on the synthesis and transport of assimilates from the leaves to fruits [29]. Role of the high temperatures in transfer of the fruit, during fruit ripening is known [30]. As low night temperatures reduce the soluble solids content [31]. Therefore, it is believed that high levels of soluble solids content in Kashan and Yazd climates than the Kiasar and Sari climates, related to the higher the day and night temperature in these areas. Based on the results of Javanmardi and Kubota [32], by studying changes in quality of tomatoes grown in greenhouse conditions showed that, Approaching the peak temperature and solar radiation Fruit titratable acid content decreased with the increase in sugar. The results of this study, the results Khanal et al. [33], to increase the soluble solids content and titratable acid reduced the fruit under different temperature conditions confirmed.

\section{Conclusion}

Based on the finding, the effect of different regional climate on persimmon fruit quality were significant $(\mathrm{P} \leq 0.01)$.It is believed that, the day and night temperature changes on the amount of vitamin $\mathrm{C}$, chlorophyll a, b and a, b activity and carotenoid content of harvested fruits was effective. Based on these findings, and considering the use of the properties of persimmon fruit in different sectors of agriculture, industry, medicine and nutrition, the importance of fruit quality should be taken into consideration more than ever.

\section{References}

1. Unal H (2004) Determination of Phenolic Compounds and Ascorbic Acid Content of Persimmon Fruit. MSc, Ankara University, Ankara, Turkey (in Turkish)

2. Baltaciglu $\mathrm{H}$, Artik N (2013) Study of postharvest changes in the chemical composition of persimmon by HPLC. Turk J Agric. 37: 568-574.

3. Vielma MS, Matta FB, Silva JL (2008) optimal harvest time of various apple cultivars grown in Northern Mississippi. J American Pomological 62: 13.

4. Kviklienè N, Kviklys D, Lanauskas J, Uselis N (2008) Harvest time effect on quality changes of apple cultivar'Alva'during ripening and storage. Sodininkystèir Daržininkystè 27: 3-8.

5. Rizzolo A, Grassi M, Zerbini PE (2006) Influence of harvest date on ripening and volatile compounds in the scab-resistant apple cultivar'Golden Orange'. Journal of horticultural science \& biotechnology 81: 681-690.

6. Juan JL, Frances J, Montesinos E, Camps F, Bonany J (1999) Effect of harvest date on quality and decay losses after cold storage of Golden Delicious apples in Girona. Acta Horticulturae 485: 195-201.
7. Zerbini PE, Pianezzola A, Grassi M (1999) Poststorage sensory profiles of fruit of five apple cultivars harvested at different maturity stages. I Food Qual 22: $1-17$

8. Ebrahimzadeh H (1990) Plant Physiology (2). University of Tehran Press 586.

9. Wahid A, Gelani S, Ashraf M, Foolad MR (2007) Heat tolerance in plants: An overview. Environmental and Experimental Botany 61: 199-223.

10. Seth D Cohen, Julie M Tarara, James A Kennedy (2011) Diurnal temperature range compression hastens berry development and modifies flavonoid partitioning in grapes. Am J Enol Vitic 63: 112-120.

11. Falcao LD, Burin VM, Sidinei Chaves E, Vieira HJ, Brighent E, et al. ( 2010) Vineyard Altitude and Mesoclimat Influences on The Phenology and Maturation of Cabernet-Sauvignon Grapes From Santa Catarina State. J Int Sci Vigne Vin $44 n^{\circ} 3$ : 135-150.

12. Mori K, Goto-Yamamoto N, Kitayama M, Hashizume K (2007) Effect of high temperature on anthocyanin composition and transcription of flavonoid hydroxylase genes in « Pinot noir » grapes (Vitisvinifera). J Hortic Sci Biotechnol 82: 199-206

13. Veberic R, Jurhar J, Mikulic-Petkovsek M, Stampar F, Schmitzer V (2010) Comparative study of primary and secondary metabolites in 11 cultivars of persimmon fruit (Diospyros kaki L.) Food Chem 119: 477-483.

14. M Del Bubba, Giordani E, Pippucci L, Cincinelli A, Checchini L, Galvan P (2009) Changes in tannins, ascorbic acid and sugar contents in astringent persimmons during on-tree growth and ripening and in response to different postharvest treatments. J Food Compos Anal, 22: 668-677.

15. A Scalbert, G Williamson (2000) Dietary intake and bioavailability of polyphenols. J Nutr, 130: 2073S-2085S.

16. Suzuki T, Someya S, Hu Fm, Tanokura M (2005) Comparative study of catching compositions in five Japanese persimmons (Diospyros kaki). Food Chem 93: 149-152.

17. Siriporn O, Chadarat D, Songoyot A, Suganya T, Sombat C (2007) Comparison of antioxidant capacity and cytotoxicites of cartain fruit peels. Food Chem 103: 839-846.

18. Arya SP (2000) Non - spectrophotometric methods for the determination of vitamin-c. Analytical Chem Acta 417: 1-14.

19. Ebrahimzadeh MA, Hosseinimehr SJ, Gayekhloo MR (2004) Measuring and comparison of vitamin $\mathrm{C}$ content in citrus fruits: introduction of nativevariety. J Chem Indian J 1: 650-652.

20. Saini RS, Sharma KD, Dhankhar OP, Kaushik RA (2001) Laboratory Manual of Analytical Techniquesin in Horticulture. Agrobios Publisher 135p.

21. Piga A, D'Aquino S, Agabbio M, Emonti G, Farris GA (2000) Influence of storage temperature on shelf-life of minimally processed cactus pear fruits. LWT-Food Science and Technology 33: 15-20.

22. Raeini M, Shiukhy S (2014) Evaluation of the effect of geographical aspects and fruit location within orange tree canopy on Sangin orange fruit quality. J Agri Meteorol 2: 57-66. 
23. Mozaffar A (1970) Plant physiology. College of Agriculture and Anima Husbandry Rezaieh Publication 665. (In Farsi).

24. Hamedani M, Rabiei V, Moradi H, Ghanbari A, Azimi MR (2012) Determination of storage duration and temperature effects on fruit quality parameters of blood orange (Citrus sinensis cv. Tarocco). Biharean Biologist 6: 10-13.

25. Ghasemi K, Ghasemi Y, Ebrahimzadeh MA (2009) Antioxidant activity phenol and flavonoid contents of 13 citrus species peels and tissues. $\mathrm{J}$ pharm Sci 22: 277-281.

26. Perveen Salma, Shinwari Kamran Iqbal, Jan Mahamood (2013) Low Temperature Stress Induced Change in Biochemical Parameters, Protein Banding Pattern and Expression of Zat12 and Myb Genes in Rice Seedling. Journal of Stress Physiology \& Biochemistry 9: 193-206.

27. Sharma R, Chahar OP, Bhatnagar M, Bhatnagar A (2013) Impact of osmotic stress and temperature on pigments and proteins of Anaboena strains. J Environ Biol 34: 941-943.

28. Zadeh Bagheri M, Kheradmand N, Sadeghi H, Nam Jahromi B (2010) Evaluation of the effect of temperature on amount of ethylene production \& quantitative and qualitative characteristics apple fruit (Malusdomestica Borkh, cv. Granny Smith). Journal of Plant and Ecosystem 6: 33-44. (In Farsi).
29. Riga P, Anza M, Garbisu C (2008) Tomato Quality Is More Dependent on Temperature than on Photosynthetically Active Radiation. Journal of the Science of Food and Agriculture 88: 158-166.

30. De koning ANM (1989) The Effect of Temperature on Fruit Growth and Fruit Load of Tomato. Acta Horticulturae 248: 329-336.

31. Qi H, Hua L, Zhao L, Zhou L (2011) Carbohydrate Metabolism in Tomato (Lycopersicaon esculentum Mill.) Seedlings and Yield and Fruit Quality as Affected by Low Night Temperature and Subsequent Recovery. African Journal of Biotechnology 10: 5743- 5749.

32. Javanmardi J, Kubota C (2006) Variation of lycopene, antioxidant activity, total soluble solids and weight loss of tomato during postharvest storage. Postharvest Biology and Technology 41: 151-155.

33. Khanal B, Suthaparan A, Huckstadt AB, Wold AB, Mortensen L, et al. (2013) The Efffect of High Day and Low Night Temperature on Pollen Production, Pollen Germination and Postharvestv Quality of Tomatoes. American Journal of Plant Sciences 4: 19-25.

34. Mozaffari GH (2003) Principals of agricultural meteorology. Nikpendar Institute Publication 518. (In Farsi).

Copyright: (c) 2015 Soqanloo SS. This is an open-access article distributed under the terms of the Creative Commons Attribution License, which permits unrestricted use, distribution, and reproduction in any medium, provided the original author and source are credited. 